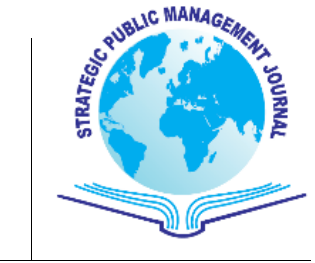

\section{Merkezi Yönetim-Yerinden Yönetim İlişkileri: İspanya ve Türkiye Üzerine Karşılaştırmalı Bir Analiz*}

Central Administration-Local Administration Relations: A Comparative Analysis on Spain and Turkey

Sefa USTA ${ }^{1}$ Erdal BİLGİç
Strategic Public Management Journal Volume 3, Special Issue, pp. 121-137 December 2017 DOI: $10.25069 /$ spmj.344707 Received: 16.10.2017 Accepted: 29.12.2017 (C) The Author(s) 2017 For reprints and permissions: http://dergipark.gov.tr/spmj

$\ddot{O} z$

Parlamenter monarşinin hüküm sürdüğ̈̈ Ispanya ile parlamenter cumhuriyetin hakim olduğu Türkiye'de yerinden yönetim sistemlerinin karşılaştırmalı olarak ele alınması çalışmanın temel amacını ve kapsamını oluşturmaktadır. Buradan hareketle çalışmanın önemi, İspanya ve Türkiye'de yerelleşme çabaları dikkate alınarak, merkezi yönetim-yerinden yönetim ilişkilerinin birincil ve ikincil kaynaklar vasitasıyla ve karşılaştırmalı perspektifle irdelenerek benzerliklerin ve farklılıkların ortaya konulmasıdır. Çalışmada, İspanya ve Türkiye'de yönetimler arası ilişkilerin değerlendirilmesinde karşılaştırmalı yöntemden yararlanilmıştır.

Anahtar Kelimeler: Merkezi Yönetim, Yerinden Yönetim, Yönetimler arası İlişkiler, Yerel Yönetimler, Karşılaştırmalı Analiz

\begin{abstract}
The main purpose of the study is to compare local administrations of Spain which has parliamentary monarchy and Turkey which is dominated by parliamentary republic. The key to working from here is to show the similarities and differences of central administration-local administration relations, using comparative perspective and primary and secondary resources and taking into account localization efforts in Spain and Turkey. In the study, comparative method is used in evaluating the relations between the governments in Spain and Turkey.
\end{abstract}

Key words: Central Administration, Local Administration, Intergovernmental Relations, Local Administrations, Comparative Analysis.

\footnotetext{
* Bu makale 13-14 Nisan 2017 tarihleri arasında III. Stratejik Kamu Yönetimi Sempozyumu'nda sözlü olarak sunulan ve özet olarak basılan bildirinin tam metin halidir.

${ }^{1}$ Yrd. Doç. Dr., Karamanoğlu Mehmetbey Ü., İ.İ.B.F., Siyaset Bilimi ve Kamu Yönetimi Bölümü, sefausta@kmu.edu.tr,

${ }^{2}$ Arş. Gör., Karamanoğlu Mehmetbey Ü., İ.İ.B.F., Siyaset Bilimi ve Kamu Yönetimi Bölümü, erdalbilgic@kmu.edu.tr
} 


\section{GíRIŞ}

Karşılaştırmalı kamu yönetimi çalışmaları, 1940'lardan itibaren kamu yönetimi alanının öne çıkan çalışma alanlarından olmuştur. Zaman zaman bu alan kamu yönetimi alanında çalışanların gündeminden düşse de karşılaştırmalı çalışmalara kamu yönetimi alan yazınında son yıllarda artan şekilde yer verilmektedir. Karşılaştırmalı çalışmalarda ülkelerin siyasal ve yönetsel yapıları ele alınarak, iki ülkenin benzerlikleri ve/veya farklılıkları ortaya konulmaya çalışılmaktadır.

Bu eksende hazırlanan çalışma kapsamında öncelikle İspanya'nın siyasal ve yönetsel yapısı genel hatlarıyla ele alınmaktadır. Daha sonra, yasama, yürütme ve yargı erkleri üzerinden genel bir çerçeve çizilerek esas konuyu oluşturan merkezi yönetim ve yerinden yönetim birimleri incelenerek, İspanya'da bölgesel ve yerel yönetimlere yönelik tarihsel süreç içerisinde gerçekleştirilen reform çalışmalarına değinilmektedir. Bu yapılırken göz önüne alınması uygun görülen temel kriter ise merkezi yönetim-yerinden yönetim ilişkileri bağlamında yerinden yönetim birimlerinin ne derecede merkezi yönetimin etkisi ve yönlendirmesi altında kaldığıdır. Bu kriter ekseninde yapılan esas değerlendirme ise karşılaştırılan ülkelerde yerinden yönetim birimlerinin idari ve mali özerkliğe sahip olup olmadığı ve desantralizasyon düzeyinin hangi seviyede olduğudur.

\section{1. İSPANYA'NIN SIYYASAL VE YÖNETSEL YAPISI}

İspanya Anayasasının ilk maddesinde de vurgulandığı gibi; İspanya, sosyal ve demokratik hukuk devletidir. Ulusal egemenlik, devlet gücünün kendisinden kaynaklanmış İspanyol halkınındır. İspanyol devletinin yönetim biçimi parlamenter monarşidir (Adalet Bakanlığı, 2011: 539).

\subsection{Siyasal Yapı}

İspanya'da 1975-1978 yılları arasında demokratik ve bölgesel talepler yükselmiş ve henüz 1978 Anayasası kabul edilmeden 13 bölgeye ön özerklik statüsü yasa-kararnamelerle tanınmıştır (Nalbant, 1997: 271). İspanya'nın bugünkü anayasası 6 Aralık 1978'de kabul edilmiş ve 29 Aralık 1978 yılında etkin olarak kullanılmaya başlanmıştır (DESA, 2006: 2). İspanya, kralın devletin başında bulunduğu parlamenter bir monarşidir. Üniter devlet ilkesine dayanır. Senato ve meclis olmak üzere iki kademeli bir yasama organı ve bağımsız bir yargı organı olduğu ifade edilmektedir (Tuna, 2003: 109).

Ülke; kentler, eyaletler ve otonom bölgelere ayrılmıştır. 17 tane otonom bölge, 2 özerk şehir ve 50 il mevcuttur. Her otonom bölgenin temel kurumsal normları kendi yasalarını oluşturur. Her otonom bölgenin kendi yasaları olduğu gibi yerel olarak kullandıkları dilleri de vardır (DESA, 2006: 2).

\subsubsection{Yasama Organı}

Anayasanın 66. maddesine göre, Parlamento, İspanyol halkını temsil eder ve Kongre ile Senato'dan meydana gelir. Parlamento devletin yasama gücünü ifa eder, bütçelerini onaylar, hükümetin icraatını denetler ve Anayasa ile verilen diğer yetkileri kullanır. Ayrıca, Parlamento dokunulmazlığa sahiptir. Kongre, anayasanın 68. maddesine göre en az 300 en çok 400 adet gizli oylama ile kanunun belirttiği şartlarda seçilmiş milletvekillerinden oluşur. Kongre, dört seneliğine seçilir. Milletvekillerinin görevi seçildiklerinden itibaren dört sene sonra ya da meclisin feshi halinde sona erer. İspanya parlamento düzeyinde Kongre, yasama işlemlerinin yapıldığı asıl meclis olup, Senato'ya oranla daha geniş yetkilerle donatılmıştır. Kongre'nin yasama ve yürütmenin denetlenmesi olmak üzere iki ana görevi bulunmaktadır (Parlak ve Caner, 2005: 330331; Adalet Bakanlığı, 2011:552-553). 
Kongre ayrıca, hükümeti oluşturma ve sona erdirme yetkisine de sahiptir. Kongre, yasaların ve bütçelerin ilk görüşüldüğü yerdir. Kongrenin kabul ettiği yasa tasarıları Senato'ya gönderilir. Senato kabul eder veya veto eder ya da bazı maddeleri değiştirebilir. Bu değişikliklerden bazıları kongrenin onayına gitmek zorundadır. Yasama faaliyeti komisyonlar oluşturularak yapılır. Kongre üyeleri dört yıl için seçilirler (Adalet Bakanlı̆̆g, 2011:553).

Anayasanın 69. maddesinde düzenlenmiş olan "Senato", bölgesel (territoryal) temsil esasına dayanmaktadır. Senatonun en önemli işlevi, ülkenin toprak bölümlenmesine göre temsilidir. Anayasa gereği, özerk topluluklar Senato'da temsil edilirler. Senato'nun temel görevi, bağlı özerk bölgeler ile diğer yönetsel bölgelerin eşit sayıda temsil edilmesi, yerel ve bölgesel politikaların yerine getirilmesidir. Senato'nun diğer görevleri ise; özerk bölge meclislerinin faaliyetlerini anayasaya aykırılık ve bağımsızlık istemi açısından denetlemek, kongre tarafından gönderilecek yasaları onaylamak, anayasa değişikliklerini kabul veya reddetmek ve hükümet çalışmalarını denetlemektir (Adalet Bakanlığı, 2011:553-557-558).

\subsubsection{Yürütme Organı}

Yürütme organı, kral ve hükümetten oluşmaktadır. İspanya Anayasası'nın 56. maddesine göre, kral devletin başı, birliğinin ve sürekliliğinin sembolüdür. Kurumların düzgün işleyişini sağlar ve gözetir. Uluslararası ilişkilerde İspanya Devletini, özellikle İspanya ile tarihsel bağı olan ulusları en üst düzeyde temsil eder ve Anayasa ve yasaların kendisine verdiği diğer işlevleri yerine getirir. Anayasanın 97. maddesinde belirtildiği gibi, hükümet, hukuki ve askeri yönetim yapısının başında bulunmaktadır. Genel olarak, iç ve dış politikayı ve devletin savunması görevlerini üstlenir. Anayasa ve kanunlara uygun olarak yürütme işlevini ve düzenleyici yetkisini icra eder. Hükümet, başbakan, başbakan yardımcıları, bakanlar ve kanunla tesis edilebilecek diğer üyelerden oluşur (Adalet Bakanlığı, 2011:559).

\subsubsection{Parlamento ve Hükümet Arasındaki İlişkiler}

Anayasanın 108. maddesinde vurgulandığı gibi hükümet siyasi faaliyetlerinden dolayı, Kongre’ye karşı müştereken sorumludur. Kongre, hükümete kanun hükmünde kararname çıkarma yetkisi verebilir. Ayrıca, temel yasaları etkilememek kaydıyla, hükümet tarafindan acil durumlarda hükümet kararnameleri çıkarılabilir. Ancak bunlar 30 gün içinde Kongre tarafından oylanmalıdır (Tuna, 2003: 112; Adalet Bakanlığı, 2011:557). Meclisler ve komisyonları, ihtiyaç duydukları bilgiyi, kendi başkanları aracılığıyla, Hükümetten ve devlet dairelerinden ve devletin herhangi bir kurumundan veya Özerk Topluluklardan isteyebilir. Meclisler ve komisyonlar Hükümet üyelerini toplantıya çağırabilir. Hükümet üyeleri Meclislerin ve komisyonların toplantısına katılma ve konuşma hakkına sahiptir ve kendilerine bağlı dairelerinden görevlilerin buralarda rapor vermesini isteyebilirler. Hükümet ve her bir üyesi Meclislerdeki genel görüşme önerilerinin (gensoru) ve soruların muhatabı olabilir (Adalet Bakanlığı, 2011:561).

\subsubsection{Yargı Organı}

Ülke çapında tek yargı düzeni vardır ve yargı erki bağımsızdır. Yargı Erki Genel Konseyi, Yargıtay, Sayıştay ve Anayasa Mahkemesi yargı düzeni içinde yer almaktadır. Yargısal sisteminin başında anayasal meseleler hariç, ülkenin en üst mahkemesi olan Yüksek Mahkeme (Yüce Divan) bulunmaktadır (Tuna, 2003: 112).

Yargı Erki Genel Konseyi yargının sevk ve idaresinden sorumludur. Başlıca işlevleri, yargı mensuplarının atanması ve meslek içinde etik standartların muhafazasıdır.

Anayasanın 159-165 arasındaki maddelerinde düzenlenen, Anayasa mahkemesi, Kral tarafından atanan 12 üyeden oluşur. 4'ü üyelerinin 5'te 3 çoğunluğu ile Kongre tarafından, 4' ü aynı çoğunluk ile Senato tarafından, ikisi hükümet tarafından ve ikisi de yargının genel meclisi tarafindan aday gösterilir. Anayasa 
Mahkemesi'nin üyelerinin tümü mesleğinde en az 15 yıllık tecrübeye sahip, sulh yargıçları, savcılar, üniversite profesörleri, kamu görevlileri ve avukatlar arasından tayin edilir. Anayasa Mahkemesi'nin üyeleri, 9 yıllığına atanır ve her 3 yılda bir mahkemenin 1/3'ü yenilenir. Anayasa Mahkemesi üyeleri başka hiçbir temsili görev alamazlar, siyasi parti veya sendika yöneticiliği yapamazlar veya bu hizmetlerde görev alamazlar, mesleki veya ticari vb. hiçbir işte bulunamazlar. Anayasa Mahkemesi'nin üyeleri görevleri süresince bağımsızdırlar ve azledilemezler. Anayasa Mahkemesi'nin birçok görevi olmakla birlikte temel görevi yasaların ve yasa gücündeki normatif düzenlemelerin Anayasa'ya uygunluğunu denetlemektir (Adalet Bakanlığ $1,2011: 575-577)$.

Anayasanın 123.maddesine göre, İspanya'nın tamamında yargı yetkisi olan Yargıtay, Anayasal güvencelerle ilişkin hükümlerle ilgili olanlar dışında, hukukun tüm dallarında en yüksek yargı organıdır. Yargıtay Başkanı, Hâkimler Genel Kurulu'nun kanunla belirlenen şekilde önerilerek Kral tarafından atanır (Adalet Bakanlığı, 2011:564).

Devletin ve kamu sektörünün hesapları ve ekonomik yönetiminin denetlenmesinden sorumlu en üst anayasal organ (Tuna, 2003: 113) ve yüksek kamu yarg1sı sıfatıyla görev yapan Sayıştay, parlamentonun ve bütün kamu tüzel kişiliklerinin harcamalarını yerinde denetleyen bir kurumdur. Yasal bir düzenlemeyle yetki ve sorumlulukları belirlenen Sayıştay üyeleri, Yargı Konseyi'nin önerisiyle Kongre tarafindan seçilmektedir (Parlak ve Caner, 2005: 341). Sayıştay üyeleri yargıç güvencesine sahip olup bağımsızdırlar (Tuna, 2003: 113).

\section{2. İspanya'nın Yönetim Yapısı}

İspanya'da Anayasa ile ülke için yeni bir yönetim modeli getirilmiştir. Üç kademeli yönetim yapısı a) Merkezi Yönetim b) Bölgesel Yönetim (Özerk Topluluklar) c) Yerel Yönetimler (Belediyeler, İller ve Diğer Yerel Yönetim Birimleri) şeklinde oluşmuştur. İspanya'nın yönetim yapısına hakim olan ilkeler Anayasa'nın 103. maddesinde belirtilmiştir. Buna göre kamu yönetimi, tarafsız olarak kamu yararına hizmet eder ve adalet ve kanunlara uygun olarak, verimlilik, hiyerarşi, yerinden yönetim, yetkilerin dağıtılması ve koordinasyon ilkelerine uygun olarak faaliyet gösterir. Devlet yönetiminin organları kanunlarla oluşturulur, yönetilir ve koordine edilir (Adalet Bakanlığ1, 2011:560).

\subsubsection{Merkezi Teşkilat}

Devletin genel idaresi hukuka ve yasaya uygun olarak hükümet tarafından düzenlenmektedir. Merkezi devlet idaresi, tek bir tüzel kişilik olarak hareket eder. Devlet yönetiminin sahip olduğu tüzel kişilik kamu hukuku tüzel kişiliğidir. Ancak, adem-i merkeziyet çerçevesinde ortaya çıkan yerel ve bölgesel birimlerin devletten farklı tüzel kişilikleri vardır (Esen, 2004: 344). Genel yönetim yapılanması içinde ilk olarak sembolik rolü olan kral sayılabilir. Bununla birlikte, bakanlar kurulu, başbakan, bakanlıklar ve devlet sekreterlikleri merkezi teşkilatın diğer önemli mekanizmalarıdır:

- Kral: Hükümet ve parlamentonun hazırlayıp kabul ettiği yasaları onaylar ve yayımlar. Parlamentoya toplanması için çağrıda bulunur ve şartlar oluştuğunda onu feshedebilir. Parlamento ile görüşüp başbakanı atar ve başbakanın tavsiyesi üzerine diğer bakanları belirler. Anayasa, krala bağımsız hiçbir yürütme yetkisi vermemiştir. Bütün işlemleri Başbakan veya bakanlardan birinin imzasıyla gerçekleşir. Anayasa, Kral'a üzerlerinde çok fazla etkisi olmasa da silahlı kuvvetlerin başkomutanlığını vermiştir. Kral dışişleri konusunda yetkili olmasa da uluslararası ilişkilerde İspanya'yı en üst düzeyde temsil eder (Tuna, 2003: 114). Kral'dan sonra merkezi yönetim içinde en önemli organ olarak hükümet sayılabilir. Hükümet; başbakan ve bakanlar kurulundan oluşur. 
- Başbakan: Hükümetin icraatının sorumluluğu ve hesabı başbakana aittir. Başbakan hükümet programının hazırlanıp yürütülmesini takip eder ve bakanlıkların çalışmasını koordine eder. Bakan olacak adayları belirler ve atanmak üzere krala sunar. Başbakan ayrıca, kamu hizmetindeki bazı görevlere gelecek kişileri belirler ve her vilayetteki sivil valileri seçme hakkına sahiptir (Tuna, 2003: 114).

- Bakanlar Kurulu: Başbakan, başbakan yardımcıları ve bakanlardan oluşur. Bakanlar kurulu hem politika üretir, hem de idari görevleri vardır. Bakanlıkların yönetim ve gözetimini, iç ve dış politikayı, sivil ve askeri idareyi, ülkenin savunmasına ilişkin işleri yürütür. Bütün işlerinden dolayı parlamentoya hesap verir (Esen, 2004: 344; Tuna, 2003: 115).

- Bakanlıklar: Bakanlıkların başında bakanlar bulunur. Bakanların hepsi kendi bakanlıklarından sorumludur. Bakanlar yetkilerinin bir kısmını alt kademelere devretseler de, nihai olarak başbakana karş1 sorumludurlar. Bakanlıklar, hükümet politikalarının yürütülmesi için düzenlemeler yaparlar, bakanlar kurulunun onayı gerekmeden bakanlık genel emirlerini yayınlarlar. Bakanlıklarını ilgilendiren konularda, devlet adına sözleşme imzalarlar. Politikaları ile ilgili olarak, kongreye, senatoya ya da parlamento komitelerinden herhangi birine açıklama yapmak zorundadırlar. Bakanlıkların idari organları, genel sekreterler, sekreter yardımcıları, genel teknik sekreterler, genel müdürler ve genel müdür yardımcılarıdır. Bunlar ilgili bakanın talebi, kamu yönetimleri bakanın teklifi ile yasa da belirtilen koşulları taşıyanlar arasından bakanlar kurulu kararnamesiyle atanır (Tuna, 2003: 115; Esen, 2004: 344-345). Merkezi yönetimde bakanlıkların dışında devlet sekreterlikleri de bulunmaktadır.

\subsubsection{Merkezi Yönetimin Taşra Teşkilatı}

Merkez örgütlenmesi çerçevesinde, bakanlıklar, bütün ülke içinde geçerli taşra örgütlenmelerine sahiptirler (Parlak ve Caner, 2005: 342). Merkezi yönetimin taşra teşkilatında, hükümet temsilcileri ve hükümet temsilci yardımcıları bulunur. Hükümet temsilcileri, hükümetin özerk topluluklar içindeki temsilcisidir. Her özerk toplulukta bulunur. Devletin ve onun organlarının yaptığı hizmetleri özerk topluluk çapında yönetir ve denetler. Bunlar başbakana bağlıdır, başbakanın önerisi ve bakanlar kurulu kararnamesiyle atanır ve görevden alınır. Devletin genel idaresinin özerk topluluk içinde koordinasyonunu sağlar. Hükümet temsilcilerinin çalışmalarında yardımcı olmak amacıyla hükümet temsilci yardımcıları da bulunmaktadır. Bunlar, birden fazla ilden oluşan özerk topluluklarda her ilde bulunur. Hükümet temsilci yardımcıları, merkezi idare içinde, özerk topluluklarda veya yerel yönetimlerde çalışan memurlar arasından seçilirler. Takımadalardan oluşan, Balear ve Kanarya özerk topluluklarında her adada bir ada müdürü bulunur. Bunlar hükümet temsilcisi tarafından atanır. Hiyerarşik olarak ya hükümet temsilcisine ya da hükümet temsilci yardımcısına bağlıdır (Esen, 2004: 346-347).

\section{2. İSPANYA'DA BÖLGESEL YÖNETIM VE YEREL YÖNETIM}

Çalışmanın bu kısmında, İspanya'da bölgesel yönetim ve yerel yönetimler ile ilgili hukuki mevzuat, örgütlenmeleri, işleyiş̧i, görev ve yetkileri, mali yapıları, denetimleri, merkezi yönetim-bölgesel yönetimyerel yönetim ilişkileri irdelenmektedir.

\subsection{Devletin Bölgesel Teşkilatlanması}

1978 İspanya Anayasasının getirdiği en önemli yeniliklerden biri, 1931 yılındaki anayasa örnek alınarak oluşturulan özerk topluluklar modelidir. Devlet bölgesel olarak şehir, il ve kurulabilecek Özerk Topluluklar halinde teşkilatlanmıştır. Bütün bu organlar, kendi işlerinin yönetimiyle ilgili özyönetim hakkına sahiptir (TBMM, 2012:38) Devlet, birlik ilkesinin etkin uygulamasını güvence altına alır, İspanya’nın farklı bölgeleri 
arasında adil ve yeterli ekonomik denge kurulmasını temin eder ve adalarla ilgili koşullara özel dikkat sarf eder. Devlet topraklarının her yerinde tüm İspanyollar aynı haklara ve yükümlülüklere sahiptir. Hiçbir makam, doğrudan ya da dolaylı, İspanyol topraklarında dolaşım ve yerleşme özgürlügünü ve malların serbest dolaşımını engelleyecek önlemler alamaz (Adalet Bakanlığı, 2011:567).

\subsubsection{Hukuki Çerçeve}

İspanya Anayasasın 2, 4, 137, 138. maddeleri ve 143'den 158'e kadar olan maddeleri özerk topluluklarla ilgilidir. Anayasanın 2. maddesinde İspanya'nın bir üniter devlet olduğu düzenlenmiş, bununla birlikte milliyet ve bölgelerin özerklik hakları ile tümü arasındaki dayanışmanın tanınacağı ve güvence altına alınacağı da vurgulanmıştır. Anayasanın 4. maddesinde ise kuruluş yasaları özerk topluluklara; özel bayraklar ve amblemler tanıyabileceği ve bunların kendi kamu binalarında ve resmi törenlerde İspanyol bayrağının yanında kullanılabileceği düzenlenmiştir. İspanya Anayasasının 143 ve 144. maddelerinde, bölgelerin oluşturulmasında ya da özerk topluluk oluşturulmasında belli esaslar getirmiştir. Özerk bir topluluğun oluşturulması için öncelikle, ulusal parlamentodaki, o bölgenin milletvekillerinden bir bölge kurucu meclisi oluşturulmaktadır. Bu kurucu bölge meclisi, anayasayı o bölgenin genel özelliklerini dikkate alarak, İspanya Anayasası'nın hükümleri çerçevesinde hazırlanıp, kabul etmektedir. Daha sonra bu anayasa halkoyuna sunulmakta ve parlamentoda onaylanmaktadır. Özerk topluluklar aralarında federasyon oluşturamazlar, ancak kendi aralarında bazı ortak işlerin yerine getirilmesi amacıyla ve Parlamentonun onayı ile bölgeler arası anlaşma yapabilirler (Keleş, 1993: 18; IULA-EMMA-Başbakanlık TOKİ: 1993: 67; Adalet Bakanlığ1, 2011:569).

\subsubsection{Organları}

Her bölgenin parlamentosu ya da bölge meclisi, kendine özgü mahkemesi ve başkan ve yürütme organından oluşan yürütme organı mevcuttur (Erten, 1999: 72). Kimileri, statülerinde yaptıkları düzenlemelerle kamu denetçisi, ekonomik ve sosyal konsey, danışma konseyi gibi organlara da yer vermiştir (Esen, 2004: 349). Bölgesel yönetimin organları şu şekilde sıralanabilir:

- Bölge Meclisi; karar organıdır. Bölge meclisi üyeleri 4 yıllık bir süre için nispi temsil usulüne göre ve genel oyla o bölgenin halkının oyuyla seçilirler. İller seçim çevresi olarak alınır (IULA-EMMABaşbakanlık TOKİ, 1993: 67; Erten, 1999: 72). Bu meclisler özerk yönetimleri temsil eder, yasama gücünü yürütür, bölge bütçesini onaylar ve hükümet icraatını kontrol ederler.

- Hükümet (Yürütme) Kurulu; yürütme organıdır. Başkan ve yürütme kurulundan oluşur. Başkan topluluk meclisi tarafından, kendi üyeleri tarafından seçilir ve kral tarafından atanır. Başkan siyasal açıdan sorumluluk taşıyan kişi olarak, topluluğun en üst temsilcisidir. Başkan üyeleri ve başkan yardımcısını serbestçe atayıp, görevden alabilir. Başkan yürütme kurulunun çalışmalarının yönetiminden ve eşgüdümünden sorumludur. Bölge statüsünde reformlar yapılması teklifini getirip, siyasal bir projede güvenoyu isteyebilir. Başkan, özerk topluluk meclisine karşı siyaseten sorumludur. Parlamento hem başkanı hem de yürütme kurulu üyelerini denetleme yetkisine sahiptir. Yürütme kurulu başkana bağlıdır. Yürütme kurulu başkan ve kurul üyelerinden oluşur. Özerk toplulukların merkezi yönetimden bağımsız, kendi kamu yönetimi teşkilatı vardır. Ancak, kamu yönetimi teşkilatının merkezi devletten ayrı bir tüzel kişiliği yoktur. Birden fazla ilden oluşan özerk topluluklarda, merkezi yönetiminkine benzer bir taşra teşkilatı yapılanması görülmektedir (Esen, 2004: 350). 


\subsubsection{Yetki ve Görevleri}

İspanya Anayasası özerk toplulukların hangi konularda tek başlarına yetkili olduklarını belirtmiştir. Bunlar genel olarak; tarım, turizm, hayvancılık, ormancılık, kültür, sulama işleri, toplumsal hizmetler, sağlık, ekonomik gelişme, çevrenin korunması, tarihsel yapıtların korunması yerel yönetim sınırlarının saptanması olarak sayılabilir (Keleş, 2006: 86). Anayasanın 148. maddesinde özerk toplulukların sabit olan görevleri düzenlenmiştir. Özerk topluluklar kimi görevlerini de merkezi yönetimle birlikte paylaşmakta ve gerçekleştirmektedir (Keleş, 1993: 19). Devletin ayrıcalıklı yetkisini kullandığı, özerk toplulukların tek başına alamadığı alanlar ve konular Anayasanın 149. maddesinde sayılmıştır (Adalet Bakanlığı, 2011:570).

\subsubsection{Denetimi}

Bölgesel topluluklar, merkezi hükümet organlarınca çeşitli şekillerde denetime tabi tutulmaktadırlar. Bunlar şu şekilde sıralanabilir (Türker, 1999: 395-397; Esen, 2004: 353; Ünüsan, 1996: 157-159):

- Vesayet Denetimi: Bölgelerin iş ve işlemleri üzerinde devletin genel bir kontrol yetkisi (idari denetim yetkisi) bulunmamaktadır.

- Bölgesel İdarelerin İslemleri Üzerinde Kontrol Yetkisi: Bölgesel düzeyde yasalar, özerk yönetimlerin hükümete, devletin kurallarına uymalarını kontrol yetkisi vermektedir. Parlamentonun hükümet temsilcisi aracılığıyla bölgesel yönetimlerden her türlü bilgiyi alma yetkileri bulunmaktadır. Hükümetin bölge organlarınca kabul edilen kararlar ve çözümlere Anayasa Mahkemesi'ne itiraz hakkı bulunmaktadir.

- Bölgesel İdarelerin Faaliyetleri Üzerinde Denetim: Özerk topluluklar öncelikle Anayasa Mahkemesi tarafindan denetlenir. Anayasa'nın 153. maddesinde özerk yönetimlerin faaliyetleri üzerinde bir yetki anlaşmazlığı durumunda, Anayasa'ya aykırılık iddiasının olması durumunda, özerk yönetimin kararları hakkında başvuru yapılması durumlarında Anayasa Mahkemesi aracılığılla bir denetim yürütüleceği belirtilmiştir (Adalet Bakanlığı, 2011:574).

- Yerindelik Denetimi: Bölgesel düzeyde yerindelik denetimi yoktur. Özerk yönetimin, bölgenin kamu yararını ciddi olarak ihlal etmesi durumunda, hükümet özerk yönetim başkanına, gerekli ihtarı yaptıktan sonra, özerk yönetime vermiş olduğu yetkileri kendisi kullanabilir.

- Mali Denetim: Özerk yönetimlerin ekonomik hesap denetimi (bütçe denetimi) Sayıştay tarafından yapılmaktadır. Sayıştay bazı yetkilerini, özerk yönetimce oluşturulan yerlerde, Bölge Sayıştay’ına devredebilir.

\subsubsection{Bölgesel (Özerk) Toplulukların Mali Yapısı}

İspanya Anayasası, bölgelerin mali bakımdan kendi kendilerine yeterliliğini garanti altına almıştır. Bölge yönetimlerine belli alanlarda kendi vergilerini koyma yetkisi tanımıştır. Bölgenin gelir kaynakları arasında, devlet vergilerinden elde edilen paylar, bölgeler arası denkleştirme payı, konut gibi hizmet alanlarında merkezden yapılan doğrudan yardımlar sayılabilir (IULA-EMMA-Başbakanlık TOKİ, 1993: 68). Mali açıdan özerk yönetimlerin gelirleri, devletin doğrudan özerk yönetimlere bırakılabileceği vergiler, devlet vergilerine eklenerek toplanan vergiler, paylaşılan (ortak) vergiler ve yeni vergi konulması şeklinde elde edilmektedir. Özerk toplulukların öz gelirleri; net emlak vergileri, veraset ve intikal vergisi, KDV, tüketim vergisi, kumardan alınan vergiler ve diğer ücretlerdir. Özerk yönetimler ayrıca, kanunla devlet tarafından kendilerine bırakılan vergilere ilave yapma imkanı vermiştir. Bunun yanında, özerk yönetimler gelir vergisi ve emlak vergisi gibi devlet vergilerinden ilave bir miktar para toplayabilirler. Özerk yönetimler, devletin önceden vergilendirmediği ürünlere yeni vergiler koyabilirler, maliyetini aşmamak kaydıyla hizmet sunulması için 
vergiler koyabilirler. Son olarak, özerk yönetimlerin, vergi, harç ve özel yardım gibi toplanan miktarların tümü, toplayan özerk yönetime gitmektedir (Türker, 1999: 389-391).

\subsubsection{Merkezi Yönetim-Bölgesel Yönetim İlişkisi}

Anayasanın 150. maddesi, devlet yetkilerinin özerk yönetimlere devredilebileceğini belirtmiştir (Tuna, 2003: 135; Adalet Bakanlığı, 2011:572). Bununla birlikte özerk bölgelerle, merkezi hükümet arasındaki yetki ayrımı anayasayla belirlenmiştir. Ayrıca, anayasada özerk toplumların yetkilerini aşamalı olarak artırmalarına izin verilmektedir. Anayasanın 131. maddesi gereğince, ekonomik faaliyetlerin bir bütün olarak planlamasından merkezi hükümet sorumludur. Hükümet özerk yönetimlerin sağladığı tahminler 1şığında ekonomik planlama projeleri hazırlarlar. Anayasanın 148. maddesiyle alan planlaması tamamen özerk yönetimlerin sorumluluğuna bırakılmıştır. Şehir planları ise, devlet tarafından hazırlanan ulusal planın hükümlerine tabidir. Bir diğer önemli noktada, özerk topluluklarda, hükümetin temsilcisi olan kişi, devlet yönetiminin o bölge içindeki teşkilatlarını yönetmek ve topluluk teşkilatı ile koordinasyon sağlamakla görevli olduğudur (Adalet Bakanlı̆̆g, 2011:574).

\subsection{Yerel Yönetimler}

Yerel yönetimler, belediyeler ve illerden oluşmaktadır. Anayasa (md.140), tam tüzel kişiliği olan şehirlerin özerkliğini güvence altına alır. Yönetim, Belediye Başkanları ve Meclis Üyelerinden oluşan Şehir Konseylerine aittir. Meclis Üyeleri şehir halkı tarafından genel, eşit, serbest ve gizli oyla, kanunun belirlediği şekilde seçilir. Belediye Başkanları Meclis Üyeleri veya şehir halkı tarafından seçilir (Adalet Bakanlığı, 2011:568).

\subsubsection{Hukuki Çerçeve}

1978 Anayasanın 137, 140, 141, 142, 149 ve 152. maddeleri yerel yönetimler birimlerine ilişkin hükümler içermektedir. Anayasa, yerel yönetimler için başlıca üç ilke öngörmüştür. Bunlar, yerel organların üyelerinin demokratik seçimle işbaşına gelmesi, yönetsel özerklik ve mali özerkliktir (Ünüsan, 1996: 4; Esen, 2004 : 354; Adalet Bakanlığı, 2011:567-574). Yerel Yönetimler Yasası'nda (1985) genel olarak yerel yönetimlerin kuruluşu, organları, görev ve yetkilerine ilişkin düzenlemeler yer almaktadır (Esen, 2004: 354). Yasada ayrıca, belediyelerin sorumluluklarının nüfuslarının büyüklükleri oranında değişeceği, yerel yönetimlerin sağlık ve eğitim konularında sorumluluklarını bölgesel yönetimle paylaşacakları vurgulanmıştır (Tuna, 2003: 126).

2 Nisan 1985 tarihli “Yerel Yönetimler (Mahalli İdareler) Temel Kanunu”nun temel ilkeleri şu şekilde sıralanabilir (Keleş, 1993: 14):

- Yerel yönetim birimlerinin neler olduğu anayasa da sayılmış ve anayasal güvence altına alınmıştır. Belediye sınırları içinde yetki sahibi olan birimler belediyelerdir;

- Yasa, yerel yönetimlere, yerel toplulukları yönetmek, kendilerini ilgilendiren işleri görmek üzere serbestçe örgütlenmek, vergi koymak gibi yetkiler tanımıştır;

- Devlet ve özerk toplulukların parlamentoları; belediyelerin, illerin, adaların ve öteki yerel kuruluşların kendilerini doğrudan ilgilendiren bütün işlere karışma haklarını almakla yükümlüdür.

\subsubsection{Yerel Yönetim Birimleri}

1978 İspanya Anayasası ile ülke için yeni bir yönetim modeli getirilmiştir. Anayasa ile merkezi bir yönetim yapısı yerine, daha desantralize bir yönetim modeli benimsenmiştir (IULA-EMMA-Başbakanlık TOKİ, 1993: 
63). Bu bağlamda yerel yönetim birimleri olarak; iller, belediyeler ve diğer yerel yönetimler (metropolitan belediyeler, gönüllü belediye birlikleri, alt yönetim bölgeleri (comarcas), belediye alt yerel yönetimleri) s1ralanabilir.

\subsubsection{1. İller}

Anayasanın 141. maddesiyle illere ilişkin bir düzenleme getirilmiştir. Buna göre, il, devletin faaliyetlerini yerine getirmek için, şehirlerin bir araya gelmesiyle ve bölgesel bölümleme ile belirlenen, kendi tüzel kişiliği olan yerel bir oluşumdur. Bir başka ifadeyle, iller devletin yer esasına göre kurulmuş bir bölümüdür. İl, İspanyol idare hukukuna göre, hem yerel ve merkezi hizmetlerin görülmesinde kullanılan bir yerel yönetim birimi hem de bir seçim çevresidir (Esen, 2004: 354; Adalet Bakanlı̆̆ı, 2011:552, 568). İl sınırları, tarihsel, coğrafi, kültürel ve din özelikleri dikkate alınarak çizilmiştir. İllerin idaresi ve illerin özerk yönetimlerinin yetkisi İl Konseylerine ("Diputaciones") veya temsil karakteri olan diğer kurumlara verilir. Yerel yönetim birimi olarak bir ili il meclisi temsil etmektedir (Keleş, 1993: 16-17).

İller, il meclisleri, başkan ve başkan yardımcıları ile il idare kurulundan oluşur:

- Il Meclisi: İl yönetiminin karar organı il meclisidir. İl meclisi başkan ve nüfus oranına göre değişen sayıda üyelerden oluşur. Her belediye seçim çevresi il meclisi için bir seçim çevresidir. İl meclisi o il sınırları içinde bulunan belediye meclisi üyeleri ve belediye başkanları arasından seçilir. Seçimler 4 yılda bir yapılır. İl meclisinin görev ve yetkileri genel olarak şunlardır (Ünüsan, 1996: 62-63; Esen, 2004: 354; Türker, 1999: 363-364; Keleş, 1993: 17):

1. İlin yürütme organını denetlenmesi ve gözetimi,

2. İlin mali sisteminin onaylanması ve yetki sınırları içinde harcamaları düzenleme,

3. Planları, yönetmelikleri, il bütçesini ve ilin personel kadrolarını onaylama,

4. İlin teşkilatlanmasını sağlama,

5. Kamu idareleri ile yerel kuruluşlar arasındaki yetki çatışmalarının bildirilmesi.

- Il İdare Kurulu (Yürütme Kurulu); ilin yürütme organıdır. İlin yürütme kurulu, başkan, başkan yardımcıları ve meclis üyelerinin en çok üçte birinden oluşur. Görevleri; başkana görevlerini yerine getirmede yardımcı olmak, il meclisinin ve başkanın devrettiği görev ve yetkileri yerine getirmektir. İlin siyasal sorumlusu başkandır (Türker, 1999:364; Ünüsan, 1996:63; Keleş, 1993:17).

- Il Meclisi Başkanı: İl meclisi kendi üyeleri arasından bir başkan seçer, başkanın görev ve yetkilerinden bazıları şunlardır: Yürütme organına başkanlık etme ve ili yönetme, ili temsil etme, il meclisini temsil etme, il meclisinin sorumlu olduğu kamu hizmetlerini yerine getirme, ilin harcamalarını yapma, başkan yardımcılarını seçme, acil hallerde idari ve kanuni kovuşturmaları başlatmaktır (Esen, 2004:354; Türker, 1999: 364).

\subsubsection{Belediyeler}

1985 tarihli İspanya Yerel Yönetimler Kanunu, belediyeleri, vatandaşın toplum yaşamına katılımının temel basamağ 1 olarak tanımlamıştır. İspanyol kamu hukukuna göre belediyeler devletin temel yerel örgütlenmesi içinde temel nitelikte olan ve kamu işlerine vatandaşların katılımını sağlayan yerel yönetim birimleridir. Belediyeler tüzel kişiliğe ve özerkliğe sahip birimlerdir. Belediyeler, belediye başkanından, başkan yardımcılarından, belediye meclisinden ve belediye yürütme kurulundan oluşmaktadır (Esen, 2004:356). 
- Belediye Meclisi (Karar Organı): Belediye düzeyinde yönetim, bir belediye meclisi tarafından yürütülür. $\mathrm{Bu}$ meclisin üyelerinin seçiminde, genel oy hakkı ve nispi temsil esastır. Meclisin üye sayıları, belediyelerin nüfuslarına göre belirlenir. Ancak kanunda en az 5 üye bulunması gerektiği belirtilmiştir. Meclis üyeleri arasından belediye başkanını kendi seçer ve aralarından birini de başkan vekili olarak belirler (Keleş, 1993: 15).

- Belediye Başkanı: Belediyenin yürütme organı belediye başkanıdır. Belediye başkanı, başkan yardımcıları ve yürütme kurulu ile birlikte çalışır. Belediye başkanı, meclis üyeleri arasından yerel seçimle seçilmiş kişidir ve genellikle belediye meclisindeki çoğunluk partisinin lideridir. Belediye başkanı, belediyenin idaresini üstlenir, belediye polis gücünün başıdır ve atamalarda geniş yetkiye sahiptir (Ünüsan, 1996: 65).

- Belediye Yürütme Kurulu: Yürütme kurulu, nüfusu beş binden fazla olan belediyelerde görülür. Kurulun üyeleri, belediye başkanı tarafından atanır ve kurulun başkanı belediye başkanıdır. Kurul, 1985 tarihli yasayla oluşturulmuş ve 1999'da yapılan değişikliklerle bugünkü halini almıştır. Kurulun görevleri, belediye başkanına yardımcı olmak, belediye başkanı veya başka bir belediye organı tarafından kendisine verilmiş işleri yapmaktır (Esen, 2004: 356).

Kentin sağlı, temizlik, aydınlatma, park ve bahçeler, mezarlıklar, ulaşım, trafik zabıtası gibi görevler belediyelerin görevleri arasındadır. Kent planlaması, sosyo-kültürel ve sportif faaliyetler, sivil savunma, turizm gibi görevler ise belediyelerin üst basamaklardaki yönetim birimleriyle paylaştıkları görevlerdir (Erten, 1999: 71; Keleş, 1993: 16). Belediye düzeyinde görev ve yetkileri kamuya açık yerlerde güvenliği sağlamak, şehir planlaması, çevre koruma, sosyal hizmetler, altyapı hizmetleri ile kültürel ve sportif faaliyetlerdir (Türker, 1999: 378-379; Ünüsan, 1996: 109-110).

\subsubsection{Diğer Yerel Yönetim Birimleri}

Belediyeler ve illerin dışında, mancomunidad, comarca, metropol belediyeler, çekirdek yerel yönetim birimleri diğer yerel yönetim birimleri olarak sıralanabilir (Esen, 2004: 357-358; Tuna, 2003:128)

- Mancomunidad: Kendi yetki alanı içinde olan ortak bir hizmeti veya bayındırlık işlerini birlikte yerine getirmek amacıyla birden fazla belediyenin gönüllü olarak bir araya gelerek oluşturdukları birliklerdir. Bunlar tüzel kişiliğe sahiplerdir. Zorunlu değil, gönüllü birliklerdir. Genellikle devletin tek başına gerçekleştirmesi durumunda yüksek maliyete sebep olacak durumlarda oluşturulur (Çöplerin toplanması, su sağlanması gibi).

- Comarca: Bunlara alt yönetim bölgeleri de denilmektedir. Comarca'nın kurulabilmesi için ya ilgili özerk topluluk veya belediyelerin girişimi gereklidir.

- Metropol Belediyeler: 1985 tarihli yasaya göre, büyük kentsel nüfusa sahip belediyelerden oluşan, kentleşmenin ve kent nüfusunun gerektirdiği ekonomik ve sosyal planlamayı yapan, belirli bayındırlık işlerini ve hizmetlerini yerine getiren yerel yönetim birimleridir.

- Çekirdek Yerel Yönetim Birimleri: Bunlara belediye altı yerel yönetim birimleri de denilmektedir. Bunların kurulması ya o yerde yaşayanların ya da ilgili belediyenin talebi üzerine gerçekleşir. Bunlar belediye sınırında kurulan, belediyeden daha küçük ölçekli yerel yönetim birimleridir. Bu yerel yönetim birimleri, belli bir nüfusun adem-i merkeziyetçi bir anlayışla yerel bir takım işleri yönetmesi amaciyla kurulurlar. 


\subsubsection{Yerel Yönetimler Maliyesi}

İspanya'da yerel yönetimlerin mali yapılarını ortaya koyabilmek için, yerel yönetimlerin gelir ve giderlerinin ortaya konulması gereklidir. Buradan hareketle, genel olarak yerel yönetimlerin gelir ve giderleri şu şekilde s1ralanabilir:

- Yerel Yönetimlerin Gelirleri: Yerel yönetimlerin gelir kaynakları şunlardır; vergi gelirleri, üst yönetimlerden sağlanan yardımlar, mali denkleştirme politikaları, harç ve resimler, borçlanma, malların yönetiminden elde edilen gelirler ve diğer kaynaklardır. Bu bağlamda gelirler içinde ilk sırayı vergi gelirleri almaktadır. Doğrudan vergi gelirleri olan emlak, alım satım, veraset ve intikal, tüketim ve şans oyunları, motorlu araçlar vergileridir (Parlak ve Caner, 2005: 356). Paylaşılan (ortak) vergiler olarak, yerel yönetimler katma değer, kurumlar ve gelir vergilerinden belli bir oranda devletten pay almaktadır (Türker, 1999: 391).

- Yerel Yönetimlerin Giderleri: Yerel yönetimlerin giderlerinin büyük bir kısmı lojman, imar, genel idare ve güvenlik masraflarıdır. Sağlık, sosyal yardım ve eğitim masrafları çok yüksek değildir. İllerin giderleri belediyelere göre daha dağınıktır. Borçlar, diğer hizmet giderleri, belediyelere verilen hisseler, sağlık harcamaları, genel idare ve güvenlik hizmetleri, toplu taşıma ve haberleşme, yol, lojman ve toplu imar düzenlemeleri illerin harcama kalemleridir (Tortop, 1994: 58).

\subsubsection{Yerel Yönetimlerin Denetimi}

İspanya'da yerel yönetimlerin denetimi farklı şekillerde gerçekleştirilmektedir. Yerel yönetimler üzerinde, idari vesayet denetiminden, yerindelik denetimine, yerel idarelerin işlemleri üzerinde kontrol yetkisinden mali denetime kadar çeşitli denetim biçimleri uygulanmaktadır:

- İdari Vesayet Denetimi: İspanya'da yerel yönetimler üzerinde vesayet prensibine dayanan kontrol sistemi 1979 yılından bu yana giderek gevşetilmiş ve 1985 yılında tam anlamıyla ortadan kaldırılmıştır.

- Yerel İdarelerin İşlemleri Üzerinde Kontrol Yetkisi: Yerel yönetimler almış oldukları kararları ve yaptıkları işlerin açıklamalı özet listesini, devlet yönetimine ve özerk yönetime 6 gün içinde duyurmakla yükümlüdür. Bu karar veya işlemler eğer hukuk düzenine aykırı ise merkezi hükümet temsilcisi veya özerk yönetim bu kararın iptalini isteyebilir (Ünüsan, 1996: 157).

- Yerindelik Denetimi: Yerel yönetimlerde yerindelik denetimi bulunmamaktadır. Yerel yönetimlerden herhangi biri İspanya'nın genel menfaatine ciddi olarak aykırı bir karar alır veya işlem yaparsa, hükümet temsilcisi bunun düzeltilmesi için yerel yönetim başkanına gerekli düzeltmeyi yapması için ihtarda bulunur. Eğer düzeltme yapmaz ise icraatı durdurabilir ve gerekli tedbirleri alabilir. Durdurma tarihinden itibaren 6 gün içinde idari mahkemeye başvurmalıdır (Türker, 1999: 396).

- Mali Denetim: Yerel yönetimler kamu muhasebe sistemine tabidirler. Devlet idari birimleri, yerel idareler muhasebe sistemlerini belirlerler. Yerel yönetimlerin dış hesap ve ekonomik idare denetimi Sayıştay tarafından gerçekleştirilir (Adalet Bakanlığı, 2011:567).

\subsubsection{Merkezi Yönetim Yerel Yönetim İlişkisi}

Yerel Yönetim kanununa göre, yerel yönetimlerle merkezi yönetim arasındaki ilişkileri, koordinasyonu ve işbirliğini sağlamak amacı ile İspanya Yerel Yönetimler Kurulu (Konseyi) oluşturulmuştur. Devletin, özerk toplulukların ve yerel yönetimlerin temsilcilerinden oluşan ve tüzel kişiliği bulunan kurulun, yerel yönetimleri ilgilendiren bütün yasal ve idari düzenlemelerde görüş bildirmek, araştırmalar yapmak, reform çalışmaları yapmak ve yerel yönetim yardım kriterleri hazırlamak görevleri bulunmaktadır (Keleş, 1993: 16). 
Merkezi yönetim bütün yerel yönetimler üzerinde denetleme ve düzenleme yetkisine sahiptir. Merkezi yönetim ile yerel yönetimler arasındaki ilişkilerin düzenlenmesinde görev ve hizmet ölçütü kullanılmaktadır. Görev bakımından merkezi yönetim; ulusal güvenlik, adalet, eğitim politikaları, dış ticaret gibi genel politikaları oluşturmak ve düzenleyici işlem yapmak durumundadır. Bu konularda merkezi yönetim yetkilerini doğrudan devretmez ve kullanılmasına izin vermez. Genel politikaların dışında kalan bütün düzenlemeler ve hizmetler yerel yönetimlere bırakılmıştır. Ayrıca, merkezi yönetim kendi kamu görevlileri dışında yerel yönetimlerin görevlilerini belirleme esasına karışamaz ancak meslek memurluğunun geliştirilmesinde, memurların eğitiminde genel politikaların saptanması noktasında son kararları alabilir (Parlak ve Caner, 2005: 358).

Belediyelerin bazı karar ve eylemleri için bir üst yönetimin onayına ihtiyaç vardır. İl yönetimlerinin başında hükümet tarafindan atanan vali bulunmaktadır. İlin işlerinin yönlendirilmesinden ve eşgüdümünden vali sorumludur. İlin birçok karar ve işlemi merkezin denetimine tabidir (IULA-EMMA-Başbakanlık TOKİ: 1993: 68).

\section{SONUÇ YERINE: TÜRKIYE VE İSPANYA MERKEZI YÖNETIM-YERINDEN YÖNETIM İLIŞKILLERININ KARŞILAŞTIRILMASI}

İki ülke mukayeseli olarak ele alındığında, Tablo 1'de görüleceği üzere, İspanya ve Türkiye'de Kara (Kıta) Avrupa'sı geleneği hüküm sürmektedir. İki ülkede üniter devlet yapısına sahiptir. Farklı olarak, İspanya için bölgesel yönetimlerin ön planda olduğu bölgesel/bölgeselleşmiş devlet ifadeleri de kullanılmaktadır.

Tablo 1: İspanya ve Türkiye'nin Siyasal ve Yönetsel Yapılarının Karşılaştırılması

\begin{tabular}{|l|l|l|}
\hline & TÜRKIYY & İSPANYA \\
\hline Devlet Yapıları & Üniter & Üniter \\
\hline Siyasal Yapıları & Parlamenter Cumhuriyet & Parlamenter Monarşi \\
\hline İdari Yapıları & Merkeziyetçi & Adem-i merkeziyetçi \\
\hline Hukuk Sistemi & Kita-Avrupası Geleneği & Kıta-Avrupası Geleneği \\
\hline Yasama Düzeni & Tek Kanatlı (TBMM) & Çift Kanatlı (Senato ve Kongre) \\
\hline Yürütme Düzeni & Çift Başlı & Çift Başlı \\
Cumhurbaşkanı-Bak. Kurulu & Krakanlar Kurulu \\
\hline Yargı Düzeni & $\begin{array}{l}\text { Düalist Yargı Düzeni } \\
\text { Adli Yargı/İdari Yarg1 }\end{array}$ & Yargılamada Birlik \\
\hline $\begin{array}{l}\text { Devlet } \\
\text { Teşkilatlanması }\end{array}$ & $\begin{array}{l}\text { Merkezden Yönetim } \\
\text { Yerinden Yönetim }\end{array}$ & $\begin{array}{l}\text { Merkezi Yönetim } \\
\text { Bölgesel Yönetim } \\
\text { Yerel Yönetim }\end{array}$ \\
\hline
\end{tabular}

Kaynak: Adalet Bakanlığ1, 2011; TBMM, 2012; Nalbant, 1997; Tuna, 2003; Parlak ve Caner, 2005; Esen, 2004; Tokgöz vd., 2009; Eryılmaz, 2016 kaynaklarından yararlanılarak tablo oluşturulmuştur

Tablo 1'de görüleceği üzere, İspanya hukuk düzeni yargılamada birlik ilkesine göre işlemektedir. Bunun yansıması olarak, İspanya'da tek yarg1 sistemi hakimdir. Buna karşın Türkiye'de düalist yarg1 düzeni hakimdir. Kamu hukuku-özel hukuk ayrımının var olduğu Türkiye'de hukuk sistemi, adli yargı-idari yargı biçiminde şekillenmiştir.

Parlamenter yönetim anlayışının var olduğu Türkiye ile karşılaştırıldığında İspanya'da parlamenter monarşi sisteminin yürürlükte olduğu dikkati çekmektedir. Burada vurgulanması gereken bir diğer husus İspanya'da 
kralın, sembolik de olsa yönetim sürecinde söz sahibi olmasıdır. Bu durum ülkede parlamenter monarşi sisteminin var olduğunun bir göstergesidir.

İspanya'da kral ve hükümet, yürütmenin iki kanadını oluştururken, Türkiye'de de yürütme görevi Cumhurbaşkanı ve Bakanlar Kurulu'ndadır. Ayrıca, Türkiye'de Cumhurbaşkanın siyasi sorumsuzluğu bulunurken, görev ve yetkileri sembolik nitelikte değil, icraidir. İspanya'da çift kanatlı yasama sisteminin (Kongre ve Senato) var olduğu görülürken, Türkiye'de yasama işlevi sadece Türkiye Büyük Millet Meclisi tarafından yerine getirildiğinden, tek kanatlıdır.

Üniter devlet sisteminin var olduğu İspanya'da adem-i merkeziyetçi; Türkiye'de ise merkeziyetçi yönetim anlayışının hüküm sürdüğü ifade edilebilir. Bununla birlikte, devlet teşkilatlanması açısından bakıldığında, İspanya'da merkezi yönetim, bölgesel yönetimler ve yerel yönetimler faaliyetlerini yürütürken, Türkiye'de merkezden ve yerinden yönetim kuruluşları (coğrafi ve hizmet yerinden yönetim kuruluşları) işlev ve faaliyetlerini sürdürmektedir.

Tablo 2: İspanya'da Bölgesel Yönetimler

\begin{tabular}{|c|c|}
\hline $\begin{array}{ll}\text { Bölgesel } & \text { Yönetimlerin } \\
\text { Dayanakları } & \\
\end{array}$ & Anayasal dayanağı var. \\
\hline Yönetimlerin & $\begin{array}{l}\text { Bölge Meclisi } \\
\text { Yürütme Kurulu } \\
\text { Başkan }\end{array}$ \\
\hline $\begin{array}{l}\text { Bölgesel Yönetimlerin İşlev } \\
\text { ve Faaliyet Alanları ile } \\
\text { Yetki ve Görevleri }\end{array}$ & $\begin{array}{l}\text { a) Tarım, turizm, hayvancılık, ormancılık, kültür, sulama işleri, } \\
\text { toplumsal hizmetler, sağlık, ekonomik gelişme, çevrenin korunması, } \\
\text { tarihsel yapıtların korunması alanlarından tek başına yetkilidir. } \\
\text { b) Ekonomik faaliyetlerin planlanmasından merkezi yönetim sorumludur. }\end{array}$ \\
\hline $\begin{array}{ll}\text { Bölgesel } & \text { Yönetimlerin } \\
\text { Kaynakları } & \end{array}$ & $\begin{array}{l}\text { a) Devlet tarafından kısmen veya tamamen devredilen vergiler; Devlet } \\
\text { vergileri ve diğer Devlet gelirlerine sürşarj. } \\
\text { b) Kendilerine özel vergiler, tarife bedelleri ve özel resimler; } \\
\text { c) Bölgeler arası bir takas fonundan transferler } \\
\text { d) Devlet Bütçesinden alınan ödenekler; } \\
\text { e) Mülklerinden ve özel hukuk kazançlarından toplanan gelirler; } \\
\text { f) Kredi operasyonlarından elde edilen gelirler. }\end{array}$ \\
\hline $\begin{array}{l}\text { Merkezi-Yerel } \\
\text { İlişkisi }\end{array}$ & $\begin{array}{l}\text { a) Anayasal yetki ayrımı. } \\
\text { b) Hükümet temsilcisi var. } \\
\text { c) Ekonomik faaliyetlerin planlanmasından merkezi yönetim sorumludur. }\end{array}$ \\
\hline Yönetimlerin & $\begin{array}{l}\text { a) Anayasa Mahkemesi, kanun hükmünde olan düzenleyici hükümlerinin } \\
\text { anayasaya uygunluğu ile ilgili konularda; } \\
\text { b) Hükümet, 150’nci maddenin ikinci fikrasında belirtilen temsilci } \\
\text { fonksiyonların yürütülmesi konusunda, kendi görüşünü Danıştay’a } \\
\text { devrederek; } \\
\text { c) Özerk yönetim ve yönetmelikler ile ilgili idari dava yargı organları; } \\
\text { d) Mali ve bütçesel konular ile ilgili olarak Sayıştay. }\end{array}$ \\
\hline $\begin{array}{l}\text { Özerklik } \\
\text { Kapsamı }\end{array}$ & $\begin{array}{l}\text { a) Topluluğun, tarihi kimliğinin en yakın karşılığı olan adı. } \\
\text { b) Bölgesinin sınırları. } \\
\text { c)Kendi özerk kurumlarının adı, teşkilatı ve merkezi. } \\
\text { d) Anayasanın belirlediği çerçeve içinde kabul edilen yetkiler ve bunlara } \\
\text { karşıllı gelen hizmetlerin aktarılması için temel koşullar. }\end{array}$ \\
\hline
\end{tabular}


Kaynak: Adalet Bakanlığı, 2011; TBMM, 2012; Ünüsan, 1996; IULA-EMMA-Başbakanlık TOKİ: 1993; Türker, 1999; Tuna, 2003; Tortop, 1994; Parlak ve Caner, 2005; Keleş, 1993; Esen, 2004; Erten, 1999; Keleş, 2006; Tokgöz vd., 2009 kaynaklarından yararlanılarak tablo oluşturulmuştur.

Tablo 2'de görüleceği üzere, İspanya'da bölgesel yönetimlerin anayasal dayanağı bulunmaktadır. Bölgesel yönetimlerin işlev ve faaliyet alanları geniş tutulmuş, ekonomik faaliyetlerin planlanması merkezi yönetime verilerek diğer görev/yetkiler bölgesel yönetimlerin uhdesine bırakılmıştır. Güçlü gelir kaynaklarına sahip olan bölgesel yönetimlerin mali denetimi Sayıştay; hukuki ve idari denetimleri Danıştay ve idari dava yargı organları aracılığıyla gerçekleştirilmektedir. Özerk bölgesel yönetimler, Anayasanın belirlediği çerçeve içinde kabul edilen yetkilerle hizmet sunumunda bulunmaktadır.

Tablo 3: İspanya ve Türkiye'nin Yerel Yönetim Sistemlerinin Karşılaştırılması

\begin{tabular}{|c|c|c|}
\hline & TÜRKIYYE & ISPANYA \\
\hline Yerel Yönetimler & İl Özel İdaresi, Belediye, Köy & $\begin{array}{l}\text { İller, Belediyeler, Diğer Yerel Yönetim } \\
\text { Birimleri }\end{array}$ \\
\hline $\begin{array}{l}\text { Yerel Yönetimlerin } \\
\text { Dayanakları }\end{array}$ & $\begin{array}{l}\text { Anayasal dayanağ var, } \\
\text { Görev ve yetkiler kanunlarla } \\
\text { düzenlenmiștir. }\end{array}$ & $\begin{array}{l}\text { Anayasal dayanağ1 var, } \\
\text { Görev ve } \quad \text { yetkiler } \\
\text { düzenlenmiștir. }\end{array}$ \\
\hline $\begin{array}{l}\text { Yerel Yönetimlerin } \\
\text { Organları }\end{array}$ & $\begin{array}{l}\text { BELEDIYYE } \\
\text {-Belediye Meclisi; Belediye Başkanı } \\
\text {-Belediye Encümeni } \\
\text { İL ÖZEL İDARESİ } \\
\text {-Vali; İl Genel Meclisi, İl Encümeni } \\
\text { KÖY } \\
\text {-Muhtar; İhtiyar Heyeti; Köy Derneği }\end{array}$ & $\begin{array}{l}\text { İL } \\
\text {-İl Meclisi; -İl İdare Kurulu } \\
\text {-İl Meclisi Başkanı } \\
\text { BELEDİYE } \\
\text {-Belediye Meclisi; } \\
\text {-Belediye Başkanı } \\
\text {-Belediye İdare Kurulu } \\
\end{array}$ \\
\hline $\begin{array}{l}\text { Yerel Yönetimlerin } \\
\text { İşlev ve Faaliyet } \\
\text { Alanları }\end{array}$ & $\begin{array}{l}\text { Altyapı hizmetleri, eğitim, sağlık, kültür, } \\
\text { ekonomi ve ticaret, konut, çevre, şehir içi } \\
\text { ulaşım, sosyal hizmetler vd. }\end{array}$ & $\begin{array}{l}\text { Sağlık, temizlik, aydınlatma, park ve } \\
\text { bahçeler, mezarlıklar, ulaşım, trafik zabıtası } \\
\text { gibi görevlerde münhasır yetki vardır. Kent } \\
\text { planlaması, sosyo-kültürel ve sportif } \\
\text { faaliyetler, sivil savunma, turizm gibi } \\
\text { görevler ise üst basamaklardaki yönetim } \\
\text { birimleriyle paylaşılır. }\end{array}$ \\
\hline $\begin{array}{l}\text { Yerel Yönetimlerin } \\
\text { Yetki ve Görevleri }\end{array}$ & $\begin{array}{l}\text { Yetki/ Genel Yetki İlkesi hakimdir. } \\
\text { Kanunda belirtilen yetki ve görevlerle } \\
\text { sinırlı. }\end{array}$ & Genel Yetkili \\
\hline $\begin{array}{l}\text { Yerel Yönetimlerin } \\
\text { Gelirleri }\end{array}$ & $\begin{array}{l}\text { Vergiler, Harçlar, Harcamalara Katılma } \\
\text { Payları, Genel Bütçe Gelirlerinden } \\
\text { Ayrılan Paylar, Bağışlar, Borçlanmalar }\end{array}$ & $\begin{array}{l}\text { Vergi gelirleri, üst yönetimlerden sağlanan } \\
\text { yardımlar, mali denkleştirme politikaları, } \\
\text { harç ve resimler, borçlanma, malların } \\
\text { yönetiminden elde edilen gelirler ve diğer } \\
\text { kaynaklar. }\end{array}$ \\
\hline $\begin{array}{l}\text { Merkezi-Yerel } \\
\text { Yönetimler İlişkisi }\end{array}$ & $\begin{array}{l}\text { Merkezi yönetimin denetimi ve yaptırımı } \\
\text { söz konusudur. }\end{array}$ & $\begin{array}{l}\text { İspanya Yerel Yönetimler Kurulu } \\
\text { aracılığıyla işbirliği ve koordinasyon. } \\
\text { Hiyerarşik ilişki yok. } \\
\text { Merkezi yönetimin düzenleme ve denetim } \\
\text { yetkisi söz konusu. } \\
\text { Görev ve hizmet ölçütü. }\end{array}$ \\
\hline $\begin{array}{l}\text { Yönetimler Arası } \\
\text { İşbirliği }\end{array}$ & $\begin{array}{lcr}\text { Mahalli İdare } & \text { Birlikleri-İçişleri } \\
\text { Bakanlığın İznine Tabi } & \\
\text { Uluslararası } \quad \text { İşbirliği- } & \text { İçişleri } \\
\text { Bakanlığının İznine Tabi } & \\
\end{array}$ & $\begin{array}{l}\text { Gönüllü birlikler } \\
\text { Mancomunidad } \\
\text { Belediye Gönüllü Birlikleri }\end{array}$ \\
\hline
\end{tabular}




\begin{tabular}{|l|l|l|}
\hline $\begin{array}{l}\text { Yerel Yönetimlerin } \\
\text { Denetimi }\end{array}$ & $\begin{array}{l}\text { Vesayet Denetimi } \\
\text { Yargısal Denetim } \\
\text { Mali Denetim (Sayıştay) } \\
\text { Etik Denetim } \\
\text { Ombudsman Denetimi }\end{array}$ & $\begin{array}{l}\text { İdari vesayet ve yerindelik denetimi yok. } \\
\text { Yerel idarelerin işlemleri üzerinde kontrol } \\
\text { yetkisi var. İşlemler için yargıya başvurma. } \\
\text { Mali denetim(Sayıştay) }\end{array}$ \\
\hline $\begin{array}{l}\text { Yerel Yönetimlerin } \\
\text { Özerkliği }\end{array}$ & Kısıtlı özerklik & Özerk \\
\hline $\begin{array}{l}\text { Desantralizasyon } \\
\text { Düzeyi }\end{array}$ & $\begin{array}{l}\text { Düşük/Orta } \\
\text { Merkeziyetçi Yönetim Anlayışı }\end{array}$ & $\begin{array}{l}\text { Yüksek } \\
\text { Adem-i Merkeziyetçi Yönetim Anlayışı }\end{array}$ \\
\hline
\end{tabular}

Kaynak: Adalet Bakanlığı, 2011; Ünüsan, 1996; Esen, 2004; Tuna, 2003; Keleş, 1993; IULA-EMMABaşbakanlık TOKİ, 1993; Türker, 1999; Erten, 1999; Parlak ve Caner, 2005; Tortop, 1994; Tokgöz vd., 2009; Eroğlu, 2013; Eryılmaz, 2016; Şengül, 2016 kaynaklarından yararlanılarak tablo oluşturulmuştur.

Tablo 3'te görüleceği üzere, İspanya'da yerel yönetimler; belediyeler, iller ve diğer yerel yönetim birimlerinden oluşurken, Türkiye'de belediyeler, il özel idareleri ve köyler yerel yönetim birimleridir. Hem Türkiye'de hem de İspanya'da yerel yönetimlerin anayasal dayanağı bulunmaktadır. İki ülkede de yerel yönetimlerin görev ve yetkileri kanunlarla düzenlenmiştir. İki ülkede de yerel yönetimlerin geniş faaliyet alanları bulunmaktadır. Türkiye'de yerel yönetimlerin yetki ve görevleri tek tek sayılmak yerine konu olarak belirtilmiştir. Bu yönüyle, Türkiye'de yerel yönetimlerin görev ve faaliyet alanları liste (tadadi) usulü sayma yöntemi yerine yetki ve genel yetki ilkesine göre belirlenmiştir (Eryılmaz, 2016). Bunun yanında, yürüteceği işlev ve faaliyetler ilgili kanunlarda belirtilen yetkilerle sınırlı tutulmuştur. İspanya'da ise yerel yönetimler yürüteceği faaliyetler konusunda genel yetkili k1lınmıştır.

İki ülkede, yerel yönetimler ve merkezi yönetim arasındaki ilişkileri değerlendirildiğinde Türkiye'de yerel yönetimler üzerinde, merkezi yönetimin denetimi ve yaptırımı söz konusu olmaktadır. Buradan hareketle, Türkiye'de merkezi yönetimin, yerel yönetimler üzerinde hem yerindelik hem de hukukilik olmak üzere idari vesayet denetimi gerçekleştirdiği dikkati çekmektedir. Yerel yönetimler üzerinde vesayet denetimin varlığı, yerel yönetim kuruluşlarının özerkliğinin kısıtlı olmasına yol açmaktadır. İspanya'da yerel yönetimler üzerinde vesayet denetimi uygulanmamakta, merkezi idare yerel yönetimlerin işlemleri üzerinde kontrol yetkisini kullanmakta, hukuki denetim sistemi ile yerel yönetimlerin vermiş olduğu kararlarda, merkezi hükümet temsilcilerinin yerel yönetimleri yarg1 denetimine tabi tutulmaktadır. Bu yönüyle düşünüldügünde, İspanya'da yerel yönetim kuruluşlarının özerklik sahibi oluşumlar olarak değerlendirilmesi mümkündür.

Merkezi yönetim-yerel yönetim ilişkilerinin seviyesinin tespitinde önemli kriterlerden birisi de yerel yönetimlerin görevleriyle orantılı gelir sahibi olabilmeleridir. Bu konuda İspanya'da yerel yönetimlerin kendi gelir kaynaklarının yanında, gelir vergilerinden belli bir oranda devletten pay alabilmektedir. Türkiye'de ise, yerel yönetimlerin gelirleri içerisinde vergiler, harçlar, bağışlar, borçlanmalar, harcamalara katılma payları bulunsa da gelirler içerisinde en önemli kalemi genel bütçe gelirlerinden ayrılan paylar oluşturmaktadır. Buradan hareketle, Türkiye'de genel bütçeden ayrılan paylar merkezi yönetimin, yerel yönetimler üzerinde kullanabileceği bir araç olarak değerlendirilebilir.

Merkezi yönetimin yerel yönetimler üzerinde vesayet denetim araçlarından birisi de yönetimler arası işbirliği olarak değerlendirilen, Türkiye'de Mahalli İdare Birlikleri Kanunu ile düzenlenen, yerel yönetimler kendi aralarında işbirliği yapmak istediklerinde İçişleri Bakanlığı'nın iznine tabi olmalarıdır. Bununla birlikte, yerel yönetim kuruluşları, uluslararası kuruluşlara üye olmak istediklerinde de İçişleri Bakanlığı'nın izni gerekmektedir. İspanya'da, yerel yönetimler arası birliktelikler gönüllü belediye birlikler şeklinde "Mancomunidad" adı verilen birlikler aracılığıyla sağlanmaktadır. 
Sonuç olarak, karşılaştırma gerçekleştirilen iki ülkenin merkez-yerel ilişkileri ile ilgili şu değerlendirmelerde bulunulabilir. İspanya'da üniter devlet sistemi hüküm sürse de bölgesel/bölgeli devlet olarak nitelendirilmesi, özerk yönetimler, bölgesel yönetimler ve yerel yönetimlerin geniş yetkilere sahip olması, ülkede adem-i merkeziyetçi bir yönetim anlayışının var olduğunun bir göstergesidir. Buradan hareketle İspanya'da kamu yönetimi/yerel yönetim sisteminde desantralizasyon düzeyinin yüksek olduğunun söylenilmesi mümkündür. Üniter devlet sisteminin var olduğu Türkiye'de ise merkeziyetçi yönetim eğilimleri her ne kadar 2003 sonrası yerel yönetim reformları ile yumuşatılmak istenildiyse de ülkede adem-i merkeziyetçi bir yönetim anlayışına geçilememiştir. Yerel yönetimlere yetkileri ile orantılı gelir kaynaklarının sağlanamaması, yerel yönetimler üzerinde idari vesayet denetimlerinin sürmesi yerel yönetim kuruluşlarının idari ve mali açıdan özerkliklerini kısıtlamaktadır. Bu yönüyle düşünüldüğünde, 2003 öncesi döneme göre yerel yönetimlerin yetkileri ve faaliyet alanları genişletilmiş, yerel özerklikleri artırılmış olsa da Türk kamu yönetimi/yerel yönetim sisteminde desantralizasyon düzeyinin düşük olduğu yönünde değerlendirmede bulunulabilir. 


\section{KAYNAKÇA}

Adalet Bakanlığı, "Avrupa Birliği Üyesi Bazı Ülkelerin Anayasaları-İspanya", Ankara, 2011, ss.533584,http://www.adalet.gov.tr/duyurular/2011/eylul/anayasalar/ulkeana/pdf/14-\%C4\%B0SPANYA\%20533584.pdf, Erişim Tarihi: 03.04.2017

Department of Economic and Social Affairs (DESA), Kingdom Of Spain Public Administration Country Profile, http://unpan1.un.org/intradoc/groups/public/documents/un/unpan023322.pdf, (07 Nisan 2017)

Eroğlu, H. T., "İspanya'da Yerel Yönetimler", Okçu Murat Ve Özgür Hüseyin (Ed.), Dünyada Yerel Yönetimler- Örnekler- Uygulamalar, Seçkin Yayıncılık, Ankara, 2013.

Erten, M., Nasıl Bir Yerel Yönetim, Anahtar Kitaplar Yayınevi, İstanbul, 1999.

Eryılmaz, B., Kamu Yönetimi, Umuttepe Yayınları, Kocaeli, 2016.

Esen, S., "İspanya”, Birgül Ayman Güler (Ed.), Kamu Yönetimi Ülke İncelemeleri, Ankara Üniversitesi SBF, Kamu Yönetimi Araştırma Ve Uygulama Merkezi Yayını, Ankara, 2004.

Keleş, R., “İspanya'da Yerinden Yönetim”, Çağdaş Yerel Yönetimler Dergisi, C:2, S:4, 1993.

Keleş, R., Yerinden Yönetim Ve Siyaset, Cem Yayınevi, İstanbul, 2006.

Nalbant, A., Üniter Devlet, Yap1 Kredi Yayınları, İstanbul, 1997.

Parlak, B. Ve Caner C., Karşılaştırmalı Siyasal Ve Yönetsel Yapılar, Alfa Aktüel Yayınları, Bursa, 2005.

Şengül, R., Yerel Yönetimler, Umuttepe Yayınları, Kocaeli, 2016.

TBMM, Karşılaştırmalı Anayasa Çalışmaları, TBMM Basımevi, Ankara, 2012, Https://Www.Tbmm.Gov.Tr/Yayinlar/Anayasa_Calismalari.Pdf, Erişim Tarihi: 03.04.2017

Tokgöz, F. vd., Yerel Yönetim Sistemleri, TESEV Yayınları, İstanbul, 2009.

Tortop, N., “İspanya'da Yerel İdareler Ve Mali Olanakları”, Çağdaş Yerel Yönetimler Dergisi, C:3, S:6, 1994.

Tuna, G. A., “İspanya Yönetim Sistemi”, Koraltay Nidas $\quad(E d)$,, $\quad 21 . \quad$ Yüzyllda Yönetim, Türk İdari Araştırma Vakfı Yayınları, Yayın No:2, Ankara, 2003.

Türker, M., Dünyada Mahalli İdareler, İçişleri Bakanlığı Yayınları, Ankara, 1999.

Uluslararası Yerel Yönetimler

Toplu Konut İdaresi (1993),

Araştırması, Kent Basımevi, İstanbul, 1993.

Ünüsan, Teoman (1996) Avrupa'da Yerel Yönetimler, Mahalli İdareler Müdürlüğü Yayınları, No:9, Ankara. 